\title{
Reading between language and image The case of the website
}

Lectura entre el lenguaje y la imagen. El caso de la web

\section{SARAH BONCIARELLI}

Università per Stranieri di Perugia

Italia

\begin{abstract}
This paper examines the theme of online reading and the role of text and images in this context. The first part contains a bibliographic analysis of the cognitive studies dealing with the reading process. The second part is focused on the new abilities required by humans in the ongoing passage from a reading brain to a digital brain. Considerations and theoretical insights are applied to the study of two categories of digital project: digital archives and virtual museums.
\end{abstract}

Key words: semiotics, sign, symbols, symbolic languages, digital heritage
Resumen. El artículo analiza el tema de la lectura digital y el papel que juegan en este contexto las imágenes y textos. En primer lugar, se lleva a cabo un análisis bibliográfico de los estudios cognitivos (procesos mentales implicados en la lectura) en relación con el proceso de lectura. A continuación se estudia la necesidad del desarrollo de nuevas habilidades por el ser humano para pasar de un cerebro de la lectura a un cerebro digital. Consideraciones y elementos teóricos son utilizados en el estudio de dos categorías de proyectos digitales: archivos digitales y museos virtuales.

Palabras clave: semiótica, signos, símbolos, lenguajes simbólicos, cultura digital

1 Álabe $\mathrm{n}^{\mathrm{o}} 3$ - junio 2011 


\section{Reading internet}

The neurologist Maryanne Woolf is a neurologist specialized in studies of the beginnings of reading and in relating reading to human cerebral activity, with its changes and evolutions. Woolf has studied the evolution that is now in process: the passage from a reading brain to a digital brain.

With the birth of new types of writing the human brain has to face changes and evolutions, because the human being wasn't born for the activity of reading. Reading ability is something that develops and changes throughout an entire life.

The birth of reading necessitated a reorganization of the brain each time a new type of writing has been invented and the cerebral circuits of the human species were forced to make an evolutionary change. Now digital reading requires new cognitive abilities of human beings.

Maryanne Woolf has attempted to study what happens when massive amounts of information are presented at the same time to the human brain and how the Internet is going to impact on reading culture. The new reader has to change with the fruition of information that is now fragmented non-linear. Information comes to the reader in a form that is characterized by simultaneity, immediateness and contemporaneity.

An on going passage from a writing culture to a digital and visual culture is signaled.

Will digital reading see the inhibition of the development of the attentional, reflective and inferential skills of the reading brain or will it increase intellectual abilities improving the quality of life and the wisdom of the species? What is going to be lost in a new generation of digital natives that usually read from a computer? Walter Ong provides important insights into implications of contemporary digital communication modalities. He defined our time as moment of secondary orality, or a time in which orality is filtered through written language and very closely related to it. For Ong the reading of a written or printed text closes humans in on themselves. Secondary orality creates a sense of belonging to groups immeasurably bigger than those of McLuhan's 'global village'. Before the invention of writing the oral man had sense of group because there were no alternatives. In our era of secondary orality this sense is conscious and planned. The individual knows that he has to be socially aware. Ong identifies in digital communication a way to return to skills of shared 
communication, as opposed to those of a more exclusive written culture and where communication means to being part of a community (for example social networks, electronic commerce, and sharing of audiovisual texts between Internet users).

Today hypertext and virtual text gives a dimension of virtual dialogue to digital reading. McEneaney said that the dynamic action of reading and online writing brings into question the traditional roles of readers and authors, and the authority of the text. We are facing a reconfiguration of communication: a model of the authoritative author and of top-down communication being replaced by a model of communication as deeply interactive and circular. As a consequence the study of, and insight into, the development of digital reading processes and digital communication forms from multiple theoretical perspectives is becoming increasingly important, as is the development of more effective communication tools. It is important to emphasize that digital reading is correlated with the digital writing. The process of building of a web page, the choice of elements, and the placement of texts and images are aimed at improving the experience of the target reader. The digital writer has to be conscious of this and of new ways of reading. Digital writing has to be fragmented, has to use images, icons, cookies, and links to facilitate the reading experience. This is an important area for study above all due to the emerging development and transformation of the book into new forms such as the e-book.

\section{The web page}

A change is occurring from linear culture and linear reading to digital forms. The web page gives new possibilities. Information arrives from the web with two principal characteristics:

- immediacy

- apparent completeness of the information.

The text is rich in textual and graphic representations that can create multiple spaces to catalyze the attention of the user. Icons, banners, and menus give meaning at the adjunct of language and image. On - line reading faces us with new cognitive implications. For example with web pages there are browser buttons, URL syntax, cookies and teaching tags to assist understanding and memory. 
The reader participates in the construction of a new text through the act of reading. A new text is created each time it is read. Reader and author cooperate in the construction of a new text. According to Iser the construction of a new text comes into being through reading.

In the realization of a page and of a web site the author arranges and selects images and texts, but every time the user connects to the site and chooses how to proceed in reading the electronic text, a new configuration of the text is built. The reading of a single user and the construction of a customized navigation course, constitute in fact a new text.

When we consider the reading of a web text we have to consider not only how the text, icons and videos can produce meanings, but the mix of all these elements, combined with an dynamic interaction path.

\section{The homepage}

In a French study of online reading paths Desportes and Bitoun (2001) analyze the websites of the seven most important French and American electricity suppliers. The principal part of the analysis focuses on the homepage, which is the access point and the starting point of a navigation course into the heart of the web structure.

The elements of the homepage that are highlighted by the analysis are:

a) the study of visual identity codes

b) foundations of the self legitimation discourse

c) the world vision expressed through the page

Important elements in the study of the website's visual identity codes are the predominant colors, logo placement and the esthetics of the homepage.

The "foundations of the self legitimation discourse" refers to the discourse that is made through the website, the mission statement that emerges from the communication choices of the page developed by the site owner. With the analysis of the web site we will ask ourselves how visual and linguistic marks contribute to the creation of this selflegitimating discourse.

Through the website homepage is it possible to understand what view is expressed by it creators and what promises are made to the reader/user.

All these elements give interesting information about the relationships with the reader: creators may accompany and guide, or distance themselves from end users. 
The homepage of a website allows a general exploration of the contents and ensures an essential graphic-iconic language that allows the user to select information choosing, for example which part of the website to access. The homepage can be organized in a diagrammatic or a linear (time-based) form or by information areas.

\section{Links}

An interesting element of online reading is the role of links. They force the reader into an interaction with the text to take positions, and to making choices connecting different parts of the text. The author of a web page creates associations and connections through the links and attempts to drive the reading path. In this way they can create starting points and points of arrival in the text. The digital reader who is becoming accustomed to following links during the reading process has expectations about this kind of connection. He understands starting points and destination points expects to be guided along his path.

\section{The image's role}

The role played by the visual part of the electronic text is one of the central aspects of the digital communication. The page, including the electronic one, has many visual aspects. We can say that there are two different kinds of electronic images: there is the "visual in the text" and the "visual of the text". Regarding the visual of the text we can considerer the visual aspects that belong to the text. McGann considers textuality as a mix of visual elements and linguistic elements. The visual element includes a book's appearance as a material object.

Electronic textuality uses the informative resources of electronic language. The page moves horizontally and vertically in a continually mobile border and constructs the text content. When we speak about the "visual in the text" we refer to the confluence between visual and verbal and their juxtaposition. Web documents are topographical and comprise graphical and iconic elements, portions of the screen, and frames that synthesize all the information coming from the verbal. For every icon of the electronic text a corresponding operation and specific meaning may be developed through user activity. 
Beyond icons, the image can fulfill the function of para-textual apparatus in the website, such as a frontispiece or cover. The images in a website don't have only an aesthetic function, but construct a reading path and facilitate user interaction. This is the case for chromatic choices that mediate reading processes in the page and in the text.

The images can become para - textual elements and assume the role of:

- frontispieces, covers

- indexes

- captions

- $\quad$ signs of opening (titles) and textual closing

With respect to the verbal content they can:

- constructs reading paths

- accompany the text with the construction of a unit of meaning

- replace text, conveying the entire meaning

Every function can be simultaneously present and the collocation of the illustrations can constitute a vertical or horizontal flow at the same time.

\section{Cases of digital reading}

Reflection about the relationship between texts and images can be applied to two important types of existing digital projects on the Internet. Digitalization experiences can be grouped in two principal categories:

a) Perpetual and hypermedial projects that present a mix of textual and iconic materials which you can access and move around, with a markup language designed for presentation such as HTML.

b) Data of textual material designed not only for consultation, but also for structural research and analysis.

The first group is image-oriented, the second is text-oriented. The first is oriented towards presentation, the second towards analysis. In McGann's theory, digital images constitute resources that allow researchers to contact directly primary documents. The extraordinary ability to store, make available and elaborate data offered by digital media opens field of knowledge to us that would otherwise be left out. Digital archives and virtual museums are two interesting examples of the application of the above mentioned 
theoretical models. Iconic aspects and verbal elements intersect and constitute central elements. The objectives are different and become evident also from the role given to texts and images.

\section{Digital archive}

McGann said that Information Technology is important today because of one of two principal functions in the humanistic research (editorial functions and storage functions): the role of bringing forward documents from the past. For McGann the passage from a printed text to an electronic text like the passage from the manuscript to the printed text, is one of the fundamental changes in human communication. digital media store large amounts of information and can allow organizations of material that would be impossible in any printed version.

Hypertext has two important characteristics: it is always prone to content changes; is not structured to focus attention but to disperse it. The internet is characterized by a decentralized structure, is not centralized, but is a completely independent set of nodes.

The digital and hypertextual archive has a decentralized structure. The object of the digital archive is to connect the researcher with the original text (a manuscript, a printed book, or a cutting). Through this tool the researcher has the unique opportunity to contact with the original text. The final objective of the archive is to represent in a complete way the work of an artist, writer or scholar.

\section{The Virtual Museum}

The virtual museum is a collection of all kinds of texts and images which can be saved and made available online for a large audience interested in specific contents. The virtual museum organizes textual and visual contents in a virtual space and conducts the reader along a path. It can respond to several spatial and temporal needs and can make content democratically accessible.

In some cases it is necessary to gather works and documents that are geographically scattered or not organically accessible. Collections preserved in many different museums spread across great distances are joined in a virtual museum. Simultaneously, the virtual museum intends to respond to needs of conservation of contents that aren't accessible, have ceased to be available or are compromised in their 
integrity and to pass these contents on across time. In this case the electronic page becomes an instrument for conservation and transmission. The virtual museum allows a democratic and extended circulation of some contents that could otherwise only be accessible to a few people because of the fragility of the material (for example a manuscript) or because they are in some locations with difficult or limited access. The virtual museum doesn't claim exhaustiveness, but realizes a way to guide the user. Among digital archives, the virtual museum gives a growing importance to the image, a central role, because it becomes an instrument used to construct and design a reading path.

\section{The Virtual Museum of Typography and Library}

www.tipografielibrai.it

The Virtual museum of typography and libraries has been created in the context of the research project For an history of typographies and libraries of the Upper Tiber Valley. The museum constructs the history of the typography and book-selling tradition in Umbria, with particular reference to the Upper Tiber Valley between 800 and 900 AD. The intent is: i) historical, because we can study with a diachronic perspective typographies as a contribution to the evolution of the area; ii) scientific, because the $\mathrm{PhD}$ in Science of Books and Writing of the University for Foreigners - Perugia will study fields related to the history of book, to the cultural and visual analysis of the elements that compose the texts (frontispieces, covers, typographic marks, images, etc.) and to publishing; iii) technical, because it will allow the identification of technological innovations and their implications in a continually changing field and market; iv) didactic: because of the national and international diffusion of a rich cultural heritage connected to the territory.

The virtual museum can be found at the address www.tipografielibrai.it. It provides collected documents, images, testimonies referring to a specific territorial area and activities. It allows the circulation, not only at a local, but also at a national and international level of all these materials. 


\section{Analysis of the Virtual Museum}

The homepage of the Virtual Museum of Typography and Booksellers presents several elements that allow empirical application of the theoretical observations that we have made:

- The graphics and chromatic settings respect the choices of the website of the University For Foreigners - Perugia. In the homepage the logo has a very important role. The logo is bespoke designed and is black and white (Fig.1). The logo is always present even when the guests access other pages.

- The project's title For and history of typography and booksellers of the Upper Tiber Valley constitutes the title of the homepage, and it is clear from the first moment that it is a university research project with a title and a specific field; that has historical purposes; that takes into consideration the importance of typographies and also bookselling in a research sector that has to consider all these components to ensure a completeness (Fig. 2).

- Below the headline an image of typographic characters appears. The choice of this image has many meanings. It is effective from a symbolic point of view because it can express several meanings. The characters give testimony to the element of the tradition connected to typographic skills. Tradition is the opportunity to hand down knowledge and competences across centuries and through generations. The characters testify to the manual ability of a task that requires many and complex skills. The characters can be considered in a figurative sense. They can direct the eyes and the gaze to the future because the design applied to the typographic sector allows a new consideration of the conception of alphabets and characters.

- In the homepage the menu is clearly situated and has the function of guiding visitors to the website in a linear navigation.

- The structure of the menu allows sequential access to the contents, proceeding from top to down, through a path that permits access to in-depth contents. At the end of the menu, as in an ideal semiotic way, it is possible to arrive at the Photogallery, the central part of the Virtual Museum.

- In the Photogallery the presence of images gives some iconic suggestions to the user. On every single page it is possible to contextualize the images through the 
accompanying text, which allows a better understanding of the meanings and provides detailed explanations.

\section{Hipografie \\ del Tifernate}

Fig. 1: Logo project Per una storia dei tipografi e librai dell'Alta Valle del Tevere (Jonathan Pierini)

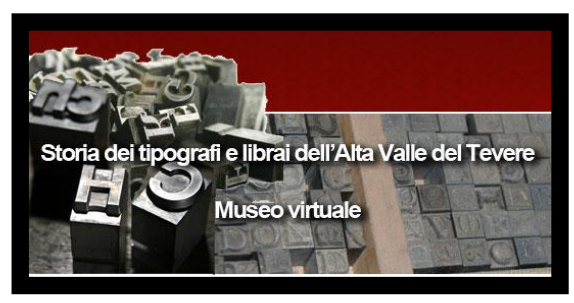

Fig. 2: Headline Museo virtuale www.tipografielibrai.it

\section{Bibliography}

Bolter, J. D. (2002). Lo spazio dello scrivere. Computer, ipertesto e la rimediazion., Milano: Vita e pensiero.

Havelock, E. (1995). La musa impara a scrivere. Riflessioni sull'oralità e l'alfabetismo dall'antichità al giorno d'oggi. Roma - Bari: Laterza.

(2006). Cultura orale e civiltà della scrittura. Da Omero a Platone. Roma - Bari: Laterza.

Legris, C. and Bitoun, C. (2001). L'analisi dei siti Internet. In Semprini A., Lo sguardo sociosemiotico. Comunicazione, marche, media, pubblicità. Milano: Franco Angeli.

Mc Eneaney, J. E., Lose, M.K., Schwartz, R.M. (2006). A transactional perspective on reading difficulties and response to intervention. International reading association.

Mc Gann, J. (2010). Radiant Textuality: Literature After the World Wide Web. Palgrave Macmillan.

McLuhan, M. (1963). La galassia Gutenberg. Nascita dell'uomo tipografico. Roma: Armando editore.

Ong, W.J.(1967). La presenza della parola Bologna, Il Mulino, 1967 (ed. orig. The presence of the Word, New Haven, Yale University Press, 1976)

- (1982). Oralità e scrittura. Le tecnologie della parola Bologna, Il Mulino (ed. orig. Orality and Literacy. The Tecnologizing of the Word. London - New York: Methuen. 
(1989). Interfacce della parola. Bologna: Il Mulino.

Woolf, M. (2009). Proust e il calamaro. Storia e scienza del cervello che legge. Vita e pensiero.

Zaganelli, G. (2008). Itinerari dell'immagine. Per una semiotica della scrittura. Milano: Lupetti.

Zaganelli, G. (2009). Oltre la città del libro. Cinque saggi sulla lettura. Milano: Lupetti.

(Artículo enviado: 21-02-2011; revisado: 03-06-2011; aceptado: 05-06-2011) 